\title{
Assessing the extinction risk of the great bustard Otis tarda in Africa
}

\author{
Carlos Palacín $^{1, *}$, Beatriz Martín², Alejandro Onrubia² ${ }^{2}$ Juan Carlos Alonso1 \\ ${ }^{1}$ Museo Nacional de Ciencias Naturales-CSIC, C/ José Gutiérrez Abascal 2, 28006 Madrid, Spain \\ ${ }^{2}$ Fundación Migres, Ctra. N-340, Km. 96.7, Huerta Grande, Pelayo, 11390 Algeciras, Cádiz, Spain
}

\begin{abstract}
We studied the dynamics and trend of the last extant population of great bustards Otis tarda in Africa. Moroccan great bustards are the southernmost population of this species, and thus show the characteristics of a peripheral population: small size, isolation and low gene flow. Available counts indicate a severe population decline (62\% in the last $15 \mathrm{yr})$, as well as a contraction of the species' distribution. We used a population viability analysis (PVA) to evaluate the quasi-extinction risk and to identify the most important threats. The estimated geometric growth rate of the more realistic of a set of possible scenarios was 0.87 (95\% CI: $0.85,0.89$ ). This implies a $13 \%$ annual decline over 50 yr. However, projections derived from these results should be interpreted with caution, because models have a great deal of uncertainty and vital rates from Iberian populations may be different from those of the Moroccan population. PVA showed the negative consequence of human-induced mortality. According to the model that best fits our census data and if present threats remain in the coming years, this peripheral population could go extinct in ca. 20 yr. Agricultural intensification, infrastructure developments and new power lines in rural areas where the species occurs are causing habitat destruction and fragmentation and increasing artificial mortality. Urgent conservation measures, especially to reduce human-induced mortality, are needed to save African great bustards from extinction. We suggest that these findings can be generalized to other peripheral great bustard populations living in highly humanized landscapes.
\end{abstract}

KEY WORDS: Bustards · Extinction · Farmland birds · Global change $\cdot$ Morocco $\cdot$ Peripheral population

\section{INTRODUCTION}

Habitat destruction and climate change induced through human activities are among the greatest threats to global bird diversity (Jetz et al. 2007). It is estimated that a large proportion of bird species breeding in the western Palearctic may be threatened in the near future if global warming continues to increase (Huntley et al. 2008). Furthermore, climate warming is expected to decrease population growth rates close to the warmest limit of a species' distribution, where climatic conditions are less suitable (Jiguet et al. 2010). Thus, peripheral populations are likely to be most affected by changes in future

\footnotetext{
${ }^{*}$ Corresponding author: cpalacin@mncn.csic.es
}

environmental conditions (Brommer \& Moller 2010). The periphery of a species range usually represents the limit of its ecological tolerance, with isolation, low gene flow and small population sizes further complicating survival. These populations are nevertheless recognized as having an important role in the survival and expansion of a species during periods of climate change (Hampe \& Petit 2005).

The great bustard Otis tarda is a large and extremely dimorphic bird that survives in highly fragmented populations across the Palearctic, from Morocco to eastern China (Palacín \& Alonso 2008). The southernmost limit of its global breeding distribution is located in northern Morocco (Alonso et al. 2005),

() The authors 2016. Open Access under Creative Commons by Attribution Licence. Use, distribution and reproduction are unrestricted. Authors and original publication must be credited. 
where the last extant African population of the species still survives, showing the characteristics of a peripheral population (small size, isolation and low gene flow). Genetic studies have identified this population as a separate management unit of high conservation concern due to isolation and genetic differentiation from nearby Iberian populations (Hellmich \& Idaghdour 2002, Alonso et al. 2005, 2009, Horreo et al. 2014). Severe habitat degradation throughout the species' distribution range caused fragmentation, population declines and local extinctions during the $20^{\text {th }}$ century, mainly in Europe, and great bustards are therefore considered as globally threatened (IUCN 2015). At present, some peripheral populations seem to be declining at the southernmost limit of the species range (e.g. in Portugal, Turkey, Iran, Kazakhstan, Russia, China and Mongolia), where remnant populations are isolated and may suffer from a lack of genetic diversity (Pinto et al. 2005, Tian et al. 2006, Kessler 2007, Karakas \& Akarsu 2009, Oparin et al. 2013, Barati et al. 2015). One possible explanation for this decline is that populations breeding close to the species thermal maximum have lower growth rates than those in other parts of the thermal range (Jiguet et al. 2010).

Sightings of great bustards in northwestern Africa at the end of the $19^{\text {th }}$ century suggest a wider distribution in the past, although the species has never been very abundant in the region (Loche 1858, Irby 1895, Vaucher \& Vaucher 1915, Whitaker 1905). At the beginning of the $21^{\text {st }}$ century several censuses were carried out in Morocco (Hellmich \& Idaghdour 2002, Alonso et al. 2005). These studies pressed for urgent conservation actions to save this extremely endangered population from extinction, but no conservation measure has been implemented. On the contrary, substantial land-use changes and infrastructural development have occurred in northern Morocco in recent years: (1) A global electrification program is currently being developed, and 526 new power lines have been constructed since 2000 in the 2 provinces where great bustards still survive (Office National de l'Electricité et de l'Eau Potable 2014). (2) The Green Morocco Plan (Ministry of Agriculture and Fisheries 2014) is promoting modern and competitive agriculture through land concentration and subsequent agricultural intensification. (3) The strengthening and modernizing of major infrastructure and superstructure networks reflects the general policy of the government. For example, $1500 \mathrm{~km}$ of roads are being built every year, and the construction of a new highway (Rabat-Tangier) crossing one of the few remaining great bustard areas was completed in 2005. Moreover, $15000 \mathrm{~km}$ of rural roads have been built since 2005 within the framework of the national program of rural roads (Ministry of Equipment and Transport 2014). (4) In 2011 the construction of Africa's first high-speed railway line was started (Casablanca-Tangier; Office National des Chemins de Fer 2014), crossing a core area of the species.

The aim of this study was to update the conservation status of this endangered population of great bustards. We conducted several censuses and performed a population viability analysis (PVA), in order to (1) determine the recent trend of this marginal population, (2) evaluate its extinction risk, (3) identify which factors have the greatest impact on the projected population performance and (4) propose recommendations for the conservation and recovery of this and other peripheral great bustard populations.

\section{MATERIALS AND METHODS}

\section{Study area}

Fieldwork was carried out in the same areas in which the maximum count of great bustards was obtained in recent years (1998-1999 winter census; Hellmich \& Idaghdour 2002), i.e. from north to south: Kanouat, Araoua, Chekbouchan, Tendafel and Tleta Rissana $\left(35^{\circ} 11^{\prime}-35^{\circ} 38^{\prime} \mathrm{N}, 5^{\circ} 51^{\prime}-6^{\circ} 02^{\prime} \mathrm{W}\right.$; the size of the surveyed areas is presented in Table 1 ; for details see Hellmich \& Idaghdour 2002 and Alonso et al. 2005). Data on land-use changes and new infrastructures (power lines, highways, high-velocity trains, rural roads and new farms) built in great bustard areas were mapped on geo-referenced maps and/or orthophotos during the surveys (2009-2014).

Table 1. Size of the surveyed areas, and number and length $(\mathrm{km}$, in parentheses) of new infrastructures observed in each area since 2005. Gaps indicate 0

\begin{tabular}{|c|c|c|c|c|c|c|}
\hline Area & $\begin{array}{c}\text { Size } \\
\left(\mathrm{km}^{2}\right)\end{array}$ & $\begin{array}{c}\text { Power } \\
\text { lines } \\
(\mathrm{km})\end{array}$ & $\begin{array}{l}\text { Highway } \\
(\mathrm{km})\end{array}$ & $\begin{array}{l}\text { High-speed } \\
\text { train line } \\
(\mathrm{km})\end{array}$ & $\begin{array}{c}\text { Rural } \\
\text { roads } \\
(\mathrm{km})\end{array}$ & $\begin{array}{l}\text { New } \\
\text { farms }\end{array}$ \\
\hline Kanouat & 32.2 & $2(5.0)$ & $1(2.6)$ & & $3(2.9)$ & 6 \\
\hline Araoua & 129.2 & $5(14.0)$ & & $1(2.0)$ & $5(23.4)$ & 18 \\
\hline Chakbouchan & 31.9 & & & & $3(6.9)$ & 9 \\
\hline Tendafel & 17.6 & & $1(7.4)$ & & & 5 \\
\hline Tletta Rissana & 28.1 & & & & & 1 \\
\hline Total & 239.0 & $7(19.0)$ & $2(10.0)$ & $1(2.0)$ & $11(33.2)$ & 39 \\
\hline
\end{tabular}




\section{Study species}

Male and female great bustards live all year round in sexually segregated flocks. The species exhibits a dispersed lek mating system, with females rearing alone their usually single precocial chick for 6 to 12 mo. In the western Palearctic, great bustards are partial migrants and differential migrants by sex, with sedentary and migratory birds of both sexes coexisting in the same breeding groups (Palacín et al. 2009b, 2011). Regarding possible movements between the Iberian Peninsula and Morocco, there have been no observations of great bustards crossing the Strait of Gibraltar in recent times (Palacín 2007). There are only a few published sightings of great bustards in northern Morocco from the end of the $20^{\text {th }}$ century: (a) in February 1982, 57 birds were seen on the plains around Tangier, 41 of them being mature males (Goriup 1983) and (b) in December 1993, 50 individuals were observed in the same area (Schollaert et al. 1994). More recently, in the winter 19981999, 90 individuals were spotted, the highest number counted in Morocco so far (Hellmich \& Idaghdour 2002).

\section{Bird censuses and population trend}

Surveys were carried out in the first half of January, when peak flock sizes occur (Martínez 1988, Alonso et al. 2004b), facilitating counts in low-density areas. Great bustards show a strong site fidelity to pre-breeding areas (94\% for males and $79 \%$ for females; Palacín et al. 2009b). Thus, annual series of censuses at the same pre-breeding areas may adequately represent the trend of local populations. We counted the total numbers of great bustards (absolute abundance), and coverage was complete in the surveyed areas. Census counts for the species require no correction for detectability (Gregory et al. 2004). Each census was conducted by a team consisting of a minimum of 3 observers with extensive experience in counting great bustards in Morocco, following itineraries at low speed, using $4 \times 4$ vehicles, with frequent and prolonged stops at vantage points, to carefully scan for birds using binoculars and telescopes (20-60x). Censuses were carried out under favorable weather conditions (no fog, rain, or wind). All flocks were mapped on geo-referenced maps and/or orthophotos. Data to estimate the population trend over time were collected by repeated censuses during 3 different pre-breeding periods (years 2009, 2011 and 2014) using the same methodology as in previous censuses. Data for 1999 are based on Hellmich \& Idaghdour (2002), and those for 2001 and 2005, on Alonso et al. (2005). We estimated both the magnitude and statistical significance of the trend in annual number of great bustards by fitting a loglinear regression of counts against year (Link \& Sauer 1998) over the study period (1999-2014). Since a trend may be defined as the geometric mean rate of population change over time (Link \& Sauer 1998), if the trend is linear, the geometric rate of change can be estimated by fitting a linear regression to the logarithm of the annual number of birds over time, where the coefficient of the slope (r) is the annual rate of change in bird numbers (Link \& Sauer 1998). Temporal correlation among regression residuals is a violation of stochastic independence, and can affect the conclusions drawn from statistical inference. Temporal autocorrelation (ACF) and partial temporal autocorrelation (PACF) functions for the regression model were inspected in order to identify statistically significant autocorrelation at any time lag.

\section{PVA model}

We used VORTEX (Lacy et al. 2009), which is an individual-based simulation model for PVA. VORTEX models both demographic stochasticity (i.e. the randomness of reproduction and deaths among individuals in a population) and environmental stochasticity (i.e. the variation in the probabilities of reproduction and survival that arises from random fluctuations in the environment). The standard deviation of the mean was used to describe the environmental stochasticity of each rate in VORTEX models (Miller \& Lacy 2005). Precise and unbiased estimation of environmental (i.e. process) variation alone, excluding sampling variation, is critical in the analysis of stochastic demographic models (White 2000). However, our estimates of stochasticity for survival and fecundity rates included sampling error (Gould \& Nichols 1998, White et al. 2002). Moreover, stochastic fluctuations in large populations are usually considered an effect of stochastic variation in the environment of the population (i.e. environmental stochasticity). This type of variation can be modeled as a stochastic change in the parameters of the model from one year to the next. In contrast, demographic stochasticity (i.e. sampling variation in births and deaths) describes the random fluctuations in population size that occur because the birth and death of each individual is a discrete and probabilistic event. Demographic stochasticity is particularly important 
for small populations because it increases the probability of extinction (Engen et al. 1998). In the case of fecundity rates, following Akçakaya (2002), we considered that demographic stochasticity constituted $<1 \%$ of the total variability (see Martín 2008 for details). However, demographic stochasticity may also be present in survival rates, recruitment rates, or in any other binomial process, such as mating probability, affecting the total amount of variability (Akçakaya 2002). In addition, different populations, even neighboring, may show quite distinct vital rates. Thus our estimates of vital rates derived from Iberian populations may not exactly match the real rates of the Moroccan great bustard population.

Environmental variation was assumed not to impact all individuals in the population simultaneously. Since we expected that weather, predators, parasites and other sources of variation outside the population affect reproduction and survival independently, we

Table 2. Parameters used for VORTEX population viability analysis. These values were obtained from the best monitored great bustard (Otis tarda) population on the Iberian Peninsula (Martín 2008 and authors' unpubl. data, see 'Materials and methods'). Age at last reproduction was based on Glutz von Blotzheim et al. (1973). Values in parentheses are SD

\begin{tabular}{|c|c|}
\hline Input parameters & \\
\hline Mating system & Polygynous \\
\hline Age at first reproduction & $4 \mathrm{yr}$ \\
\hline Age at last reproduction & $30 \mathrm{yr}$ \\
\hline Maximum brood size & 3 \\
\hline Sex ratio at birth (males:females) ${ }^{a}$ & $50: 50$ \\
\hline Reproductive rates $^{\mathrm{b}}$ & \\
\hline Breeding females (\%) & $54.2(0.32)$ \\
\hline Distribution of brood size ${ }^{\mathrm{a}}(\%)$ & \\
\hline 1 chick & 87.68 \\
\hline 2 chicks & 10.25 \\
\hline 3 chicks & 2.07 \\
\hline Mortality rates males:females (\%) & \\
\hline $0-1$ yr & $55: 49(33: 36)$ \\
\hline $1-2 \mathrm{yr}$ & $12: 10(21: 18)$ \\
\hline $2-3 \mathrm{yr}$ & $15: 12(20: 17)$ \\
\hline$>3 \mathrm{yr}$ & $27: 13(15: 10)$ \\
\hline Breeding males (\%) & 45 \\
\hline Initial population size ${ }^{\mathrm{c}}$ & 90 \\
\hline Carrying capacity & 5000 \\
\hline $\begin{array}{l}{ }^{a} \text { VORTEX allows the user to decide } \\
\text { ment of the next generation the } \\
\text { occur. We defined brood size as th } \\
\text { per family }\end{array}$ & $\begin{array}{l}n \text { the develop- } \\
\text { is defined to } \\
\text { er of offspring }\end{array}$ \\
\hline $\begin{array}{l}\text { 'Reproductive rates were measure } \\
\text { chicks were } 3-4 \text { mo old and cou } \\
\text { and sexed }\end{array}$ & $\begin{array}{l}\text { tember when } \\
\text { sily identified }\end{array}$ \\
\hline${ }^{\mathrm{c}}$ Set to reflect a stable age distribu & \\
\hline
\end{tabular}

assumed an absence of concordance in the environmental variation between survival and reproduction in the models (Miller \& Lacy 2005). Once reproductive age is reached (i.e. age at first reproduction $4 \mathrm{yr}$ ), the annual probability of mortality remains constant over the life of the individual (Miller \& Lacy 2005) thus 4 different age classes were considered for modeling survival rates (Table 2). Population growth rate (i.e. geometric growth rate, lambda) under the influence of stochastic fluctuations was calculated by random simulations repeated 1000 times. We included inbreeding depression in the model, as a reduction in first-year survival among inbred individuals (Miller \& Lacy 2005). The average impact of inbreeding on first-year survival was quantified as a number of 'lethal equivalents' per diploid individual. Inbreeding may largely vary between species. We tested whether different numbers of lethal equivalents (a range from -1.4 to 30.3 based on 40 captive mammalian populations belonging to 38 species; Ralls et al. 1988) could affect the results of our models. This sensitivity analysis of the impact of inbreeding depression on the geometric growth rate (see Fig. S1 in the Supplement at www.int-res.com/articles/suppl/ n030p073_supp.pdf) suggested that once inbreeding is included in the models, different numbers of lethal equivalents did not sensibly change the growth rate of the population. Therefore, we used the default value of 3.14 given by VORTEX, a summary statistic based on Ralls et al. (1988). To obtain meaningful data from any PVA analysis, particularly in the case of individual-based models, one has to have extensive knowledge of the focal species' biology. However, there is little knowledge on survival and reproductive rates of this African population of great bustards. Therefore, input parameters to build the models were based on the best monitored Iberian population inhabiting a similar humanized habitat. This data set was obtained by long-term monitoring of the population dynamics based on 100s of radiotracked birds and at least 2 seasonal censuses conducted each year from 1995 to the present: one census in spring to count breeding individuals and another in mid-September to determine the annual productivity (Alonso et al. 2004a, Martín et al. 2007, Martín 2008, authors' unpubl. data). When parameters from the study population are not obtainable, it is justified to use reliable VORTEX parameters obtained for other populations of the same species (e.g. Ashbrook et al. 2015). Initial population size was based on the census performed in the winter of 19981999, when the maximum number of great bustards in the last 15 yr was counted (Hellmich \& Idaghdour 
2002). To define the proportion of individuals within various cohorts, we used a stable age distribution. The model simulates the great bustard polygynous mating system; thus, there only needs to be at least 1 male for all females to have an opportunity to breed (Miller \& Lacy 2005). However, only a subset of males have opportunities to breed in the population (i.e. only some dominant adult males; Alonso et al. 2010). In addition, the number of breeding males affects the degree of inbreeding depression in the models. According to the data available, the sex ratio at birth seems to be 1:1 (H. Litzbarski pers. comm., based on a sample of 531 eggs collected for artificial breeding at Buckow Station, Germany, 1979-1998; see Martín et al. 2007). VORTEX allows the user to decide when in the development of the next generation the 'birth' is defined to occur. Fecundity was measured in September when chicks were 3-4 mo old and could be easily identified by direct observation (Alonso et al. 2004b). Brood size was also determined at this time, as the number of chicks per family. Therefore, first-year mortality rates were specified according to the time when we started to record offspring (i.e. chick survival from September).

Carrying capacity was set at 5000 individuals in order to prevent a demographic threshold. Environmental variation in carrying capacity was assumed to be unchanged during the time period of projection, although some habitats were lost due to changes in land use. However, since population size is small compared to habitat availability in the study area, habitat availability does not seem to be currently limiting population growth. A summary of the input parameters used for PVA is given in Table 2. Additional details on the assumptions and procedures of VORTEX are given in Miller \& Lacy (2005).

We modeled 4 different scenarios: (1) Firstly, we simulated a realistic scenario based on basal demographical rates. (2) In a second scenario, we examined how a reduction of human-induced mortality (simulated as a $1 \%$ reduction in the mortality rates for both sexes in all age classes) would affect the probability of population persistence. This artificial mortality rate was based on findings of Martín (2008) for central Spanish populations (human-induced mortality for adult males: $1.37 \%$, and for adult females: $0.82 \%$ ). (3) The third scenario examined the benefits of a hypothetical management scheme that would increase the number of families with 2 chicks by $10 \%$ to the detriment of 1 -chick families. The new distribution of 'brood size' under this scenario would be: 1 chick $=77.68 \%$ of families, 2 chicks $=20.25 \%, 3$ chicks $=2.07 \%$. Finally, (4) we examined a fourth scenario that was built using minimum demographic rates for survival in which we adjusted the population decrease to the counts we made over the study period (1999-2014). This scenario was built using minimum demographic rates for survival (an increase of $7 \%$ in the mortality of all sex and age classes) and fecundity (a decrease in fecundity with no family larger than 2 chicks) simulating a stronger effect of artificial human factors on the Moroccan population compared to the Iberian population from which most demographic parameters were taken. This scenario attempts to mimic the current situation of great bustards in Morocco, where there has been rapid development of human infrastructures (e.g. roads, power lines) and there are many recent examples of changes in land use (e.g. agricultural intensification). After removing families with 3 chicks, the new distribution of number of offspring per female and brood was: $1=89.16 \%$ and $2=10.84 \%$.

\section{RESULTS}

A large number of new infrastructures have been built in the areas occupied by great bustards in Morocco during the last decade (Table 1). Between 1999 and 2014, great bustard counts showed a statistically significant decrease (Table 3, Fig. 1 ; slope $=$ $-0.06 ; \mathrm{p}<0.001 ; \mathrm{R}^{2}=0.98$ ) moving from 90 to 34 birds. Broken down by sex, the decrease was $57 \%$ in males and $63 \%$ in females. Inspection of the temporal autocorrelation functions (ACF and $\mathrm{PACF}$ ) for the regression model showed no statistically significant autocorrelation for any time lag (Fig. S2 in the Supplement).

A sensitivity analysis for the parameters derived from this data set was previously conducted by incrementally varying survival and fecundity parameters, while holding all other parameters constant (see

Table 3. Great bustard (Otis tarda) counts in Morocco between 1999 and 2014. Data for 1999 were taken from Hellmich \& Idaghdour (2002), and for 2001 and 2005 from Alonso et al. (2005)

\begin{tabular}{|cccccc|}
\hline Year & $\begin{array}{c}\text { Males } \\
(>1 \text { yr old })\end{array}$ & Females & \multicolumn{2}{c|}{ Males } \\
$(<1$ yr old $)$ & $\begin{array}{c}\text { Not sexed/ Total } \\
\text { aged }\end{array}$ & \\
\hline 1999 & 21 & 62 & 4 & 3 & 90 \\
2001 & 15 & 65 & 4 & 0 & 84 \\
2005 & 10 & 60 & 1 & 0 & 71 \\
2009 & 8 & 39 & 2 & 0 & 49 \\
2011 & 8 & 31 & 2 & 0 & 41 \\
2014 & 9 & 23 & 2 & 0 & 34 \\
\hline
\end{tabular}




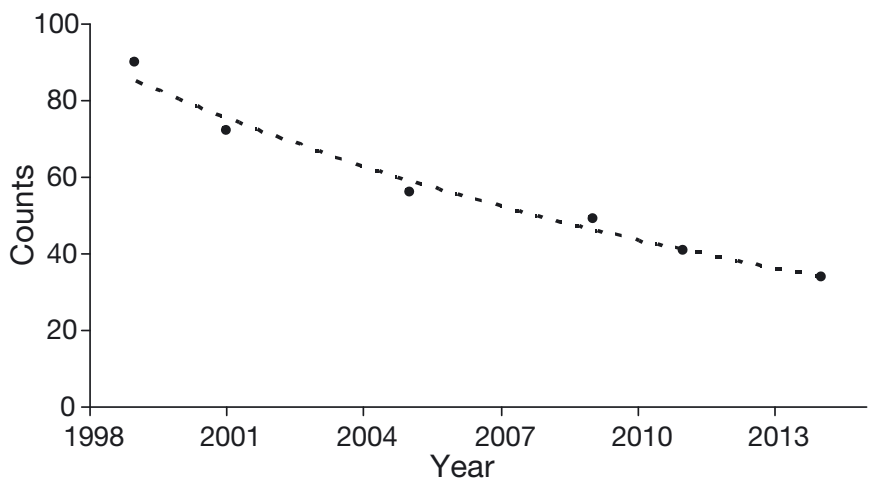

Fig. 1. Numbers of great bustards Otis tarda counted in Morocco between 1999 and 2014. Data for 1999 were taken from Hellmich \& Idaghdour (2002), and for 2001 and 2005, from Alonso et al. (2005). The line fitted to the counts follows a statistically significant decreasing trend: $\log (y+1)=$ $123.68-0.06$ year; $\mathrm{p}<0.001 ; \mathrm{R}^{2}=0.98$

Martín 2008 for details). This sensitivity analysis used a regression model to evaluate the importance of model parameters that influence the population growth rate. According to this analysis, when sensitivity is tested within the natural range of variability of the parameters (i.e. standard deviation), juvenile mortality (i.e. mortality during the first year of life) followed by adult mortality (i.e. mortality of birds older than $4 \mathrm{yr}$ ) had the greatest influence on the population growth rate. However, when sensitivity is tested beyond the natural range of variability of the parameters (i.e. beyond the parameter's standard deviation range), as a simulation of the impact of artificial mortality, we identified adult mortality as the most sensitive parameter affecting the population growth rate, followed by juvenile mortality. Female mortality (both of juvenile and adult birds) has a larger impact than male mortality on the growth rate of the population. Moreover, by comparing a deterministic model in the absence of stochasticity and an identical model including variability, we know that the population trend is not substantially modified due to the inclusion of environmental stochasticity in the models (our Fig. 2; Martín 2008).

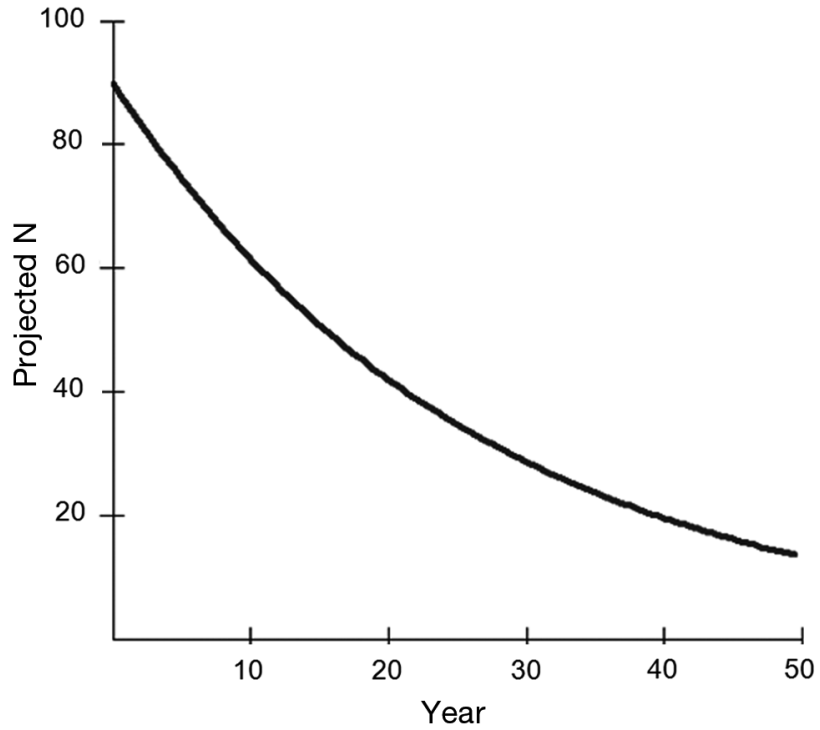

Fig. 2. Population projections for the great bustard Otis tarda in Morocco derived from the deterministic model (i.e. Scenario 1 model in the absence of stochasticity) over $50 \mathrm{yr}$

Based on the demographic parameters (Table 2), the basic scenario (Scenario 1) showed that the deterministic population growth rate estimated using VORTEX was negative $(<1)$ even in the absence of any random fluctuations. The deterministic growth rate and the growth rate including stochastic events were also negative for all other scenarios, and the $95 \%$ confidence intervals did not include the value 1 , indicating a declining trend in all cases (Table 4). This resulted in a probability of quasi-extinction within $50 \mathrm{yr}$ of $0.46-1.00$, depending on the particular scenario (Table 4, Fig. 3). Scenario 4, in which survival and fecundity rates had minimum values (Fig. 4), gave a mean time to extinction of only $20 \mathrm{yr}$ (Table 4). In relation to the basic scenario (Scenario 1), mean population size was larger and the probability of quasi-extinction decreased when we simulated considering a higher fecundity (Scenario 3), especially when mortality affecting all age and sex classes (attributed to human-induced causes) was reduced (Scenario 2). Projected sex ratios would be $2.68,2.55$,

Table 4. Summary statistics for each populations variability analysis scenario. Simulations were run to show the probability of quasi-extinction over $50 \mathrm{yr}$, and results are based on 1000 iterations

\begin{tabular}{|lcccccrrr|}
\hline Scenario & $\begin{array}{c}\text { Deterministic } \\
\text { lambda }\end{array}$ & $\begin{array}{c}\text { Stochastic } \\
\text { lambda }\end{array}$ & $\begin{array}{c}\text { Stochastic lambda } \\
-95 \% \text { CI }\end{array}$ & $\begin{array}{c}\text { Probability of } \\
\text { quasi-extinction }\end{array}$ & $\begin{array}{c}\text { Population size } \\
\text { Mean }\end{array}$ & $\begin{array}{c}\text { Mean time to } \\
\text { extinction (yr) }\end{array}$ \\
\hline 1 & 0.981 & 0.951 & 0.935 & 0.968 & 0.595 & 21.23 & 49.93 \\
2 & 0.993 & 0.963 & 0.947 & 0.979 & 0.455 & 43.25 & 124.94 & 31.5 \\
3 & 0.981 & 0.952 & 0.936 & 0.968 & 0.578 & 20.83 & 49.34 & 31.6 \\
4 & 0.894 & 0.870 & 0.854 & 0.887 & 0.997 & 0.06 & 0.60 \\
\hline
\end{tabular}




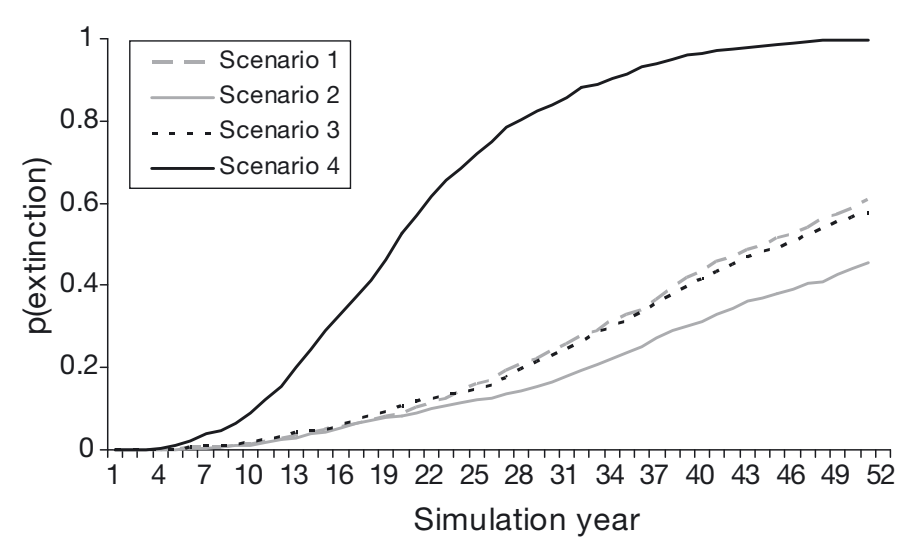

Fig. 3. Probability of quasi-extinction of great bustards Otis tarda in Morocco over 50 yr under different scenarios (see 'Materials and methods')

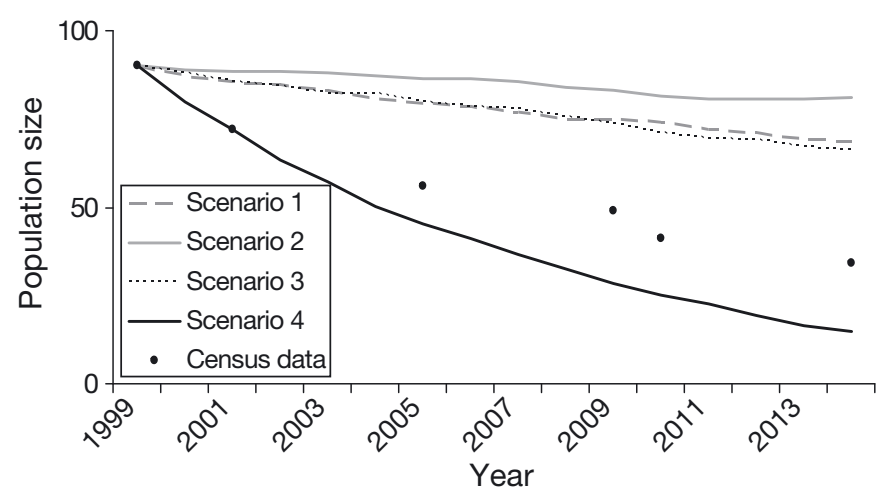

Fig. 4. Comparison between population size recorded from 1999 to 2014 and population trends under 4 different scenarios (see 'Materials and methods; PVA model'), projected over the first 16 years and taking the number of great bustards Otis tarda censused in 1999 as the initial population size. Projections based on the stochastic model

2.61 and 3.17 females per male, respectively, for Scenarios 1-4, whereas the value measured in the study population was 3.80 .

\section{DISCUSSION}

Our results show that the great bustard population of northern Africa has experienced a marked decline over the last $15 \mathrm{yr}$, and that its survival is severely threatened at present. Population trends are almost never linear, and due to the different sources of uncertainty in the data it is hard to determine to what extent observation errors may have affected our results. However, under all scenarios examined, the mean time to extinction was lower than $33 \mathrm{yr}$, and the model that best fitted our census data predicts extinction in 20 years' time. Our models indicate (1) the extremely endangered status of Moroccan great bustards, even if adult mortality is reduced by $1 \%$; (2) higher mortality rates in this southernmost population than in nearby populations (e.g. Iberian Peninsula); (3) the negative consequence of humaninduced mortality; and (4) the potential benefits of active management. It is likely that Moroccan great bustards are currently entering the final phase of their extinction process. Population projections derived from our model should be interpreted with caution, because models have a great deal of uncertainty, and vital rates from Iberian populations may be different from those of the Moroccan population. However, these models certainly draw attention to the urgent need for conservation measures to save this endangered population from extinction, and also provide useful guidelines to design management actions. In high-quality habitat areas and without artificial mortality factors (such as the legal hunting practiced in Spain until 1980, which led to several local extinctions), populations of this species could remain stable or even experience slight increases (Alonso et al. 2003, Palacín 2007).

Hunting might have been the most important cause of decline in the past (Hellmich \& Idaghdour 2002, Alonso et al. 2005), but today factors related to landuse changes and infrastructural development in Morocco, such as the change from extensive to intensive farmland regimes, expansion of urban areas and construction of infrastructures (i.e. roads, motorways, power lines and high-speed railways) are more important. A similar phenomenon has recently been described for southern Europe, where negative impacts on birds were related to economic development and habitat changes (Martínez-Abraín et al. 2009). These land-use changes surely have a negative impact on population survival through a reduction in food availability, but may also, and perhaps more importantly, have an impact through direct mortality due to collisions with power lines. Power line casualties represent the main human-induced mortality factor affecting great bustards (Martín et al. 2007, Barrientos et al. 2012, Raab et al. 2012), and may limit population growth in this species (Martín 2008). Since 2005, at least $19 \mathrm{~km}$ of new power lines have been constructed in great bustard core areas in Morocco (Table 1). As an example of the negative consequences of power lines for great bustards, a new high-voltage line sector of just $8.5 \mathrm{~km}$ built in a core area in central Spain killed a minimum of 25 individuals in only 1 yr (authors' pers. obs.).

A reduction of collision risk might have an important positive impact on the Moroccan population of 
great bustards, since collision mainly affects adult mortality, which is one of the demographic parameters with the greatest effect on lambda (Martín 2008). The best way to reduce this mortality is through the appropriate planning of new power lines. In the case of already existing power lines, possible solutions include underground cabling and wire marking with anti-collision devices (Raab et al. 2012).

A new highway and several rural roads have been constructed in great bustard areas in Morocco in recent years $(43.2 \mathrm{~km}$ in total; Table 1$)$, causing permanent habitat loss, because bustards show a tendency to avoid close proximity to these infrastructures (ca. $750 \mathrm{~m}$ threshold distance; Torres et al. 2011). The construction of a high-speed rail line crossing one of the core areas also represents a cause of direct habitat loss and a potential cause of mortality for the species. The 18 individuals killed along $22 \mathrm{~km}$ of a high-speed rail line crossing a bustard area in central Spain clearly illustrate the danger of high-speed trains (Life Impacto Cero 2014).

As for farming practices, the maintenance of traditional agriculture is a key factor for great bustard conservation (Palacín et al. 2012). Although great bustards are long-lived, and unsuitable environmental conditions in a particular year should not critically affect adult survival, female fecundity and juvenile survival are highly dependent on habitat quality (Martín 2008). In Moroccan areas used by the species at least 39 new farms have recently been built in order to develop modern and competitive agricultural structures. Agricultural intensification is one of the most important factors identified in steppe-land declines over Europe (Donald et al. 2001). It is notable that the other sympatric bustard species inhabiting extensive dry cereal farmland in Morocco, the little bustard Tetrax tetrax, has also suffered a dramatic population decline in recent decades (Palacín \& Alonso 2009a). These 2 bustard species are suffering the consequences of recent changes in farmland regimes. To promote habitat quality for bustards, management measures should be undertaken, such as the maintenance of extensive dry farmland in breeding areas and agro-chemical control to favor insects, which are essential to the diet of chicks (Bravo et al. 2012). Recent economic development, however, still coexists with ancestral farming practices. In areas where traditional agriculture persists, a high human population density can be found. Shepherds and farmers may represent a source of disturbance for great bustards in these regions, particularly during the breeding season when females require tranquility to raise their off- spring. In addition, in these rural areas, plundering of the nests and hunting are also practices that may decrease female fecundity, and also increase mortality of juvenile and adult individuals (Hellmich \& Idaghdour 2002).

Finally, climate projections in North Africa predict an increase in temperature of between 2 and $3^{\circ} \mathrm{C}$ by 2050, while precipitation is likely to decrease by between 10 and $20 \%$; this trend is most pronounced in Morocco (Schilling et al. 2012). If precipitation decreases, it is reasonable to think that Moroccan great bustards will be negatively affected in the future, because their productivity seems to be positively correlated with the precipitation of the previous winter (Morales et al. 2002). The potential distributions modeled under scenarios of climate change for the Iberian Peninsula show clear tendencies of contraction and a northward shift, and these tendencies might also affect Moroccan birds. For great bustards, the magnitude of this contraction was estimated at around 11-21\% in 2041-2070 (Araújo et al. 2011). In fact, the Iberian breeding group located closest to Moroccan great bustards was found in Cádiz (Andalucía, southern Spain), and has been extinct since 2009 (Consejería de Medio Ambiente 2011). Similar local extinctions have been reported for other peripheral populations of the Iberian peninsula in recent times (Alonso et al. 2003, Pinto et al. 2005). The predicted northward shift and contraction should particularly affect Moroccan great bustards that are located further to the south. Moreover, genetic studies suggest that great bustards colonized Morocco from the Iberian peninsula only some 1000s of years ago (Pitra et al. 2000), but today this North African population is genetically differentiated from Iberian bustards, and the Strait of Gibraltar represents an important barrier to gene flow (Horreo et al. 2014). Therefore, the Moroccan bustard population is very prone to extinction, due to its small size and demographic isolation.

In sum, active management and strict protection measures are urgently needed to prevent extinction of the great bustard on the African continent. Conservation actions should be designed to reduce artificial mortality of adult birds. Priority should be given to marking power lines with bird flight-diverters and to eliminating those line sectors crossing the main core areas of this species. Since wire marking only reduces, but does not eliminate, the risk of collision (Barrientos et al. 2012), we strongly recommend burying any power lines in breeding areas. Poaching is another cause of human-induced mortality that could be reduced through adequate surveillance, but 
this will only be possible with the cooperation of local people. It is necessary to involve local residents in protecting great bustards from poaching in Morocco. They can be made to understand the benefits of conservation measures if these are accompanied by social improvements in their rural communities (e.g. in education, transportation, communication etc.). These active conservation and management measures should be compatible with the social and economic development of the areas where great bustards live, but need to be implemented immediately if they are to be successful in saving the species from extinction in Morocco and, thus, on the entire African continent.

Acknowledgements. Special thanks to the people living in the surveyed areas for their help in the field. Thanks to Joachim Hellmich for his pioneer work with Moroccan great bustards. We also thank Benedicto Campos, Carlos Torralvo, Juan Ramírez and Andrés de la Cruz for their assistance during the surveys. The comments of Kate Ashbrook and 2 anonymous referees improved earlier drafts of this manuscript.

\section{LITERATURE CITED}

Alonso JC, Palacín C, Martín CA (2003) Status and recent trends of the great bustard (Otis tarda) population in the Iberian Peninsula. Biol Conserv 110:185-195

> Alonso JC, Martín CA, Alonso JA, Palacín C, Magaña M, Lane SJ (2004a) Distribution dynamics of a great bustard metapopulation throughout a decade: influence of conspecific attraction and recruitment. Biodivers Conserv 13:1659-1674

Alonso JC, Palacín C, Martín CA (2004b) La avutarda común en la península Ibérica, población actual y método de censo. Seguimiento de Aves 3. SEO/BirdLife, Madrid

Alonso JC, Palacín C, Martín CA, Mouati N, Arhzaf ZL, Azizi D (2005) The great bustard Otis tarda in Morocco, a re-evaluation of its status based on recent survey results. Ardeola 52:79-90

> Alonso JC, Martín CA, Alonso JA, Lieckfeldt D, Magaña M, Palacín C, Pitra C (2009) Genetic diversity of the great bustard in Iberia and Morocco, risks from current population fragmentation. Conserv Gen 10:379-390

Alonso JC, Magaña M, Palacín C, Martín CA (2010) Correlates of male mating success in great bustard leks: the effects of age, weight and display effort. Behav Ecol Sociobiol 64:1589-1600

Araújo MB, Guilhaumon F, Neto DR, Pozo I, Calmaestra R (2011) Impactos, vulnerabilidad y adaptación al cambio climático de la biodiversidad española. Fauna de Vertebrados, Dirección General de Medio Natural y Política Forestal, Ministerio de Medio Ambiente, Madrid

Ashbrook K, Taylor A, Jane L, Carter I, Székely T (2015) Impacts of survival and reproductive success on the longterm population viability of reintroduced great bustards Otis tarda in the UK. Oryx, doi:10.1017/S003060531 5000368

- Barati A, Abdulkarimi R, Alonso JC (2015) Recent status and population decline of the great bustard (Otis tarda) in Iran. Bird Conserv Int 25:377-384
Barrientos R, Ponce C, Palacín C, Martín CA, Martín B, Alonso JC (2012) Wire marking results in a small but significant reduction in avian mortality, a BACI designed study. PLoS One 7:e32569

- Bravo C, Ponce C, Palacín C, Alonso JC (2012) Diet of young great bustards Otis tarda in Spain: sexual and seasonal differences. Bird Study 59:243-251

Brommer JE, Moller AP (2010) Range margins, climate change, and ecology. In: Moller AP, Fiedler W, Berthold $P$ (eds) Effects of climate change on birds. Oxford University Press, Oxford, p 249-274

Consejería de Medio A (2011) Seguimiento de aves terrestres. Reproduccion: 2010 programa de emergencias, control epidemiológico y seguimiento de fauna silvestre de Andalucía. Junta de Andalucía, Sevilla

Donald PF, Green RE, Heath MF (2001) Agricultural intensification and the collapse of Europe's farmland bird populations. Proc R Soc B 268:25-29

Engen S, Bakke O, Islam A (1998) Demographic and environmental stochasticity - concepts and definitions. Biometrics 54:840-846

Glutz von Blotzheim UN, Bauer KM, Bezzel E (1973) Handbuch der Vögel Mitteleuropas, Vol 5. Akademie Verlag, Frankfurt

Goriup P (1983) The houbara bustard in Morocco. Report of the Al-Areen/ICBP, March 1982. Preliminary survey. ICBP, Cambridge

> Gould WR, Nichols JD (1998) Estimation of temporal variability of survival in animal populations. Ecology 79:2531-2538

Gregory RD, Gibbons DW, Donald PF (2004) Bird census and survey techniques. In: Sutherland WJ, Newton I, Green RE (eds) Bird ecology and conservation; a handbook of techniques. Oxford University Press, Oxford, p $17-56$

- Hampe A, Petit R (2005) Conserving biodiversity under climate change, the rear edge matters. Ecol Lett 8:461-467

Hellmich J, Idaghdour Y (2002) The great bustard Otis tarda population in Morocco in 1998-2001. Bird Conserv Int 12:19-33

> Horreo JL, Alonso JC, Palacín C, Mila B (2014) Genetic structure in Iberian and Moroccan populations of the globally threatened great bustard Otis tarda, a microsatellite perspective. J Avian Biol 45:507-513

Huntley B, Collingham YC, Willis SG, Green RE (2008) Potential impacts of climatic change on European breeding birds. PLoS One 3:e1439

Irby LH (1895) The ornithology of the Straits of Gibraltar. Taylor \& Francis, London

IUCN (International Union for Conservation of Nature) (2015) The IUCN Red List of Threatened Species, Version 2015-4. www.iucnredlist.org (accessed Dec 2015)

> Jetz W, Wilcove DS, Dobson AP (2007) Projected impacts of climate and land-use change on the global diversity of birds. PLoS Biol 5:e157

> Jiguet F, Devictor V, Ottvall R, Van Turnhout C, Van der Jeugd H, Lindström A (2010) Bird population trends are linearly affected by climate change along species thermal ranges. Proc R Soc B 277:3601-3608

Karakas R, Akarsu F (2009) Recent status and distribution of the great bustard, Otis tarda, in Turkey. Zool Middle East 48:25-34

Kessler AE (2007) The great bustard (Otis tarda) in Kazakhstan, from population biology to land-use planning. www.irex.org/sites/default/files/Kessler.pdf (accessed Nov 2014) 
Lacy RC, Borbat M, Pollak JP (2009) Vortex: a stochastic simulation of the extinction process, Version 9.95. Chicago Zoological Society, Brookfield, IL

Life Impacto Cero (2014) Development and demonstration of an anti-bird strike tubular screen for high-speed rail lines. LIFE+ 2012 Biodiversity project BIO/ES/000660. 2013-17. www.lifeimpactocero.com (accessed Dec 2014)

Link WA, Sauer JR (1998) Estimating relative abundance from count data. Austrian J Stat 27:83-97

Loche V (1858) Catalogue des mammifères et des oiseaux observés en Algérie. Bertrand, Paris

Martín B (2008) Dinámica de población y viabilidad de la avutarda común en la Comunidad de Madrid. PhD thesis, Universidad Complutense de Madrid, Madrid. http:// eprints.ucm.es/8614/1/T30812.pdf (accessed Dec 2015)

Martín CA, Alonso JC, Alonso JA, Palacín C, Magaña M, Martín B (2007) Sex-biased juvenile survival in a bird with extreme size dimorphism, the great bustard Otis tarda. J Avian Biol 38:335-346

Martínez C (1988) Size and sex composition of great bustard (Otis tarda) flocks in Villafáfila, northwestern Spain. Ardeola 35:125-133

Martínez-Abraín A, Crespo J, Jiménez J, Gómez JA, Oro D (2009) Is the historical war against wildlife over in southern Europe? Anim Conserv 12:204-208

Miller PS, Lacy RC (2005) VORTEX, a stochastic simulation of the extinction process, Version 9.50 user's manual. Conservation Breeding Specialist Group (SSC/IUCN), Apple Valley, MN

Ministry of Agriculture and Fisheries (2014) Green Morocco Plan. www.maroc.ma/en/content/green-Morocoo-plan (accessed Dec 2014)

Ministry of Equipment and Transport (2014) Strategy of the Ministry of Equipment and Transport. www.maroc.ma/ en/content/transport (accessed Dec 2014)

Morales MB, Alonso JC, Alonso JA (2002) Annual productivity and individual female reproductive success in a great bustard Otis tarda population. Ibis 144:293-300

Office National de l'Electricité et de l'Eau Potable (2014) Programme d'electrification rurale global. www.one.org. ma/ (accessed Dec 2014)

Office National des Chemins de Fer (2014) Ligne TangerCasa du TGV au Maroc. http://entreprise.oncf.ma/LGV/ Pages/LigneTGR-CASA.aspx (accessed Dec 2014)

Oparin ML, Oparina OS, Kondratenkov IA, Mamaev AB, Piskunov VV (2013) Factors causing long-term dynamics in the abundance of the trans-Volga great bustard (Otis tarda L.). Biol Bull 40:843-853

Palacín C (2007) Comportamiento migratorio de la avutarda común en la península Ibérica. PhD thesis, Universidad Complutense de Madrid, Madrid

Palacín C, Alonso JC (2008) An updated estimate of the world status and population trends of the great bustard Otis tarda. Ardeola 55:13-25

Palacín C, Alonso JC (2009a) Probable population decline of the little bustard Tetrax tetrax in north-west Africa. Ostrich 80:165-170

Editorial responsibility: Daniel Oro, Esporles, Spain
Palacín C, Alonso JC, Alonso JA, Martín CA, Magaña M, Martín B (2009b) Differential migration by sex in the great bustard. Possible consequences of an extreme sexual size dimorphism. Ethology 115:617-626

> Palacín C, Alonso JC, Alonso JA, Martín CA, Magaña M (2011) Cultural transmission and flexibility of partial migration patterns in a long-lived bird. J Avian Biol 42: 301-308

- Palacín C, Alonso JC, Martín CA, Alonso JA (2012) The importance of traditional farmland areas for steppe birds: a case study of migrant female great bustards Otis tarda in Spain. Ibis 154:85-95

> Pinto M, Rocha P, Moreira F (2005) Long-term trends in great bustard (Otis tarda) populations in Portugal suggest concentration in single high quality area. Biol Conserv 124:415-423

Pitra C, Lieckfeldt D, Alonso JC (2000) Population subdivision in Europe's great bustard inferred from mitochondrial and nuclear DNA sequence variation. Mol Ecol 9:1165-1170

Raab R, Schütz C, Spakovszky P, Julius E, Schulze H (2012) Underground cabling and marking of power lines, conservation measures rapidly reduced mortality of WestPannonian great bustards Otis tarda. Bird Conserv Int 22:299-306

Ralls K, Ballou JD, Templeton A (1988) Estimates of lethal equivalents and the cost of inbreeding in mammals. Conserv Biol 2:185-193

Reşit Akçakaya H (2002) Estimating the variance of survival rates and fecundities. Anim Conserv 5:333-336

Schilling J, Freier KP, Hertige E, Scheffran J (2012) Climate change, vulnerability and adaptation in North Africa with focus on Morocco. Agric Ecosyst Environ 156:12-26

Schollaert V, Moumni T, Fareh M, Gambarotta C, Pascon J, Franchimont J (1994) Chronique ornithologique du G.O.M.A.C. pour 1993. Porphyrio 6:1-108

Tian XH, Liu Z, Bai SY (2006) Microsatellite analysis of genetic diversity of the great bustard Otis tarda dybowskii. Acta Zool Sin 52:569-574

Torres A, Palacín C, Seoane J, Alonso JC (2011) Assessing the effects of a highway on a threatened species using before-during-after and before-during-after-controlimpact designs. Biol Conserv 144:2223-2232

Vaucher H, Vaucher A (1915) Liste des oiseaux observés au Maroc de 1884 à 1914. Rev Fr Ornithol 8:155-156

Whitaker JIS (1905) The birds of Tunisia, Vol 2. RH Porter, London

White GC (2000) Population viability analysis: data requirements and essential analyses. In: Boitani L, Fuller TK (eds) Research techniques in animal ecology: controversies and consequences. Columbia University Press, New York, NY, p 288-331

White GC, Franklin AB, Shenk TM (2002) Estimating parameters of PVA models from data on marked animals. In: Beissinger SR, McCullough DR (eds) Population viability analysis. University of Chicago Press, Chicago, IL, p 169-190

Submitted: September 14, 2015; Accepted: February 11, 2016 Proofs received from author(s): March 16, 2016 